medRxiv preprint doi: https://doi.org/10.1101/2022.02.10.22270789; this version posted February 14, 2022. The copyright holder for this preprint (which was not certified by peer review) is the author/funder, who has granted medRxiv a license to display the preprint in It is made available under a CC-BY-NC-ND 4.0 International license .

\title{
SARS-CoV-2 Omicron triggers cross-reactive neutralization and Fc effector functions in previously vaccinated, but not unvaccinated individuals
}

Simone I. Richardson ${ }^{1,2}$, Vimbai Sharon Madzorera ${ }^{1,2}$, Holly Spencer ${ }^{1,2}$, Nelia P. Manamela ${ }^{1,2}$, Mieke A. van der Mescht ${ }^{3}$, Bronwen E. Lambson ${ }^{1,2}$, Brent Oosthuysen ${ }^{1,2}$, Frances Ayres ${ }^{1,2}$, Zanele Makhado ${ }^{1,2}$, Thandeka Moyo-Gwete ${ }^{1,2}$, Nonkululeko Mzindle ${ }^{1,2}$, Thopisang Motlou ${ }^{1,2}$, Amy Strydom ${ }^{4}$, Adriano Mendes ${ }^{4}$, Houriiyah Tegally ${ }^{5}$, Zelda de Beer ${ }^{6}$, Talita Roma de Villiers ${ }^{6}$, Annie Bodenstein ${ }^{6}$, Gretha van den Berg ${ }^{6}$, Marietjie Venter ${ }^{4}$, Tulio de Oliviera ${ }^{5,9}$, Veronica Ueckermann ${ }^{7}$, Theresa M. Rossouw ${ }^{3}$, Michael T. Boswell ${ }^{7}$. Penny L. Moore ${ }^{1,2,8,9^{*}}$

${ }^{1}$ National Institute for Communicable Diseases of the National Health Laboratory Services, Johannesburg, South Africa

${ }^{2}$ MRC Antibody Immunity Research Unit, School of Pathology, University of the Witwatersrand, Johannesburg, South Africa

${ }^{3}$ Department of Immunology, Faculty of Health Sciences, University of Pretoria, Pretoria, South Africa

${ }^{4}$ Zoonotic Arbo and Respiratory Virus Program, Centre for Viral Zoonoses, Department of Medical Virology, University of Pretoria, Pretoria, South Africa.

${ }^{5}$ KwaZulu-Natal Research Innovation and Sequencing Platform, Durban, South Africa; Centre for Epidemic Response and Innovation, School of Data Science and Computational Thinking, Stellenbosch University, Stellenbosch, South Africa.

${ }^{6}$ Tshwane District Hospital, Pretoria, South Africa.

${ }^{7}$ Division for Infectious Diseases, Department of Internal Medicine, Steve Biko Academic Hospital and University of Pretoria, Pretoria, South Africa

${ }^{8}$ Institute of Infectious Disease and Molecular Medicine, University of Cape Town, Cape Town, South Africa

${ }^{9}$ Centre for the AIDS Programme of Research in South Africa, Durban, South Africa 
medRxiv preprint doi: https://doi.org/10.1101/2022.02.10.22270789; this version posted February 14,2022 . The copyright holder for this
preprint (which was not certified by peer review) is the author/funder, who has granted medRxiv a license to display the preprint in It is made available under a CC-BY-NC-ND 4.0 International license

\section{Summary}

The SARS-CoV-2 Omicron variant largely escapes neutralizing antibodies elicited by vaccines or infection. However, whether Omicron triggers humoral responses that are cross-reactive to other variants of concern (VOCs) remains largely unknown. We use plasma from 20 unvaccinated and seven vaccinated individuals infected during the Omicron wave in South Africa to test binding, antibody-dependent cellular cytotoxicity (ADCC), antibody-dependent cellular phagocytosis (ADCP) and neutralization against VOCs. In unvaccinated individuals, Fc effector function and binding antibodies target Omicron and other VOCs at comparable levels. However, Omicron-triggered neutralization is not extensively cross-reactive to VOCs, with 20 to 43-fold reductions in titer. In contrast, vaccination followed by breakthrough Omicron infection improved cross-neutralization of VOCs, with titers exceeding 1:2,900. This has important implications for the vulnerability of unvaccinated Omicron-infected individuals to reinfection by circulating and emerging VOCs. Further, while Omicron-based immunogens may be adequate boosters, they are unlikely to be superior to existing vaccines for priming in SARS-CoV-2 naïve individuals.

The emergence of the SARS-CoV-2 Omicron (B.1.1.529) variant of concern (VOC) in November 2021 coincided with the fourth wave of South Africa's COVID-19 epidemic ${ }^{1}$. 
medRxiv preprint doi: https://doi.org/10.1101/2022.02.10.22270789; this version posted February 14 , 2022. The copyright holder for this preprint (which was not certified by peer review) is the author/funder, who has granted medRxiv a license to display the preprint in It is made available under a CC-BY-NC-ND 4.0 International license .

Omicron is defined by multiple mutations across its genome, including more than 30 mutations in the spike protein, many of which are associated with immune evasion ${ }^{1}$. These mutations confer neutralization escape across multiple vaccine platforms and in donors previously infected with other variants ${ }^{2-5}$.

In contrast to neutralization, antibody binding to the Omicron variant is preserved, as previously observed for other $\mathrm{VOCs}^{6,7}$. Although Fc receptor binding has been shown to be substantially reduced against $\mathrm{Omicron}^{8}$, functional Fc effector responses have not yet been reported. The ability of antibodies to bind the Omicron spike suggests that cytotoxic effector functions driven by antibodies may also be retained, as for earlier VOCs ${ }^{9,10}$. This, along with the finding that $T$ cells triggered by either infection or vaccination are cross-reactive for Omicron ${ }^{11-13}$, likely contributes to maintained vaccine effectiveness against severe disease following Omicron infection ${ }^{14}$.

While there is substantial data showing that Omicron evades neutralizing immune responses, little is known about the humoral response that Omicron infection itself triggers. Defining the capacity of Omicron to trigger cross-reactive binding, neutralizing and Fc effector responses antibodies will inform its potential to protect from reinfection by currently circulating or emerging VOCs. This is of particular relevance for developing countries such as South Africa, where vaccination levels are low and genomic surveillance indicates continued circulation of Delta and potentially C.1.2 and Beta which were still circulating in December 2021. Secondly, these data inform the potential immunogenicity of Omicron-based vaccines which are under development by several companies.

Plasma from individuals infected in the fourth wave of COVID-19 pandemic in South Africa were used to assess cross-reactivity against different VOCs for binding, Fc effector function and neutralization. Plasma was used from 27 hospitalized individuals from Tshwane District Hospital recruited between 25 November 2021 and 20 December 2021 when Omicron was 
medRxiv preprint doi: https://doi.org/10.1101/2022.02.10.22270789; this version posted February 14, 2022. The copyright holder for this preprint (which was not certified by peer review) is the author/funder, who has granted medRxiv a license to display the preprint in It is made available under a CC-BY-NC-ND 4.0 International license .

responsible for $>90 \%$ of infections ${ }^{1}$ (Table S1). Of these, seven plasma samples had matched nasal swabs available and all were confirmed as Omicron BA.1 infections by sequencing. Twenty individuals were unvaccinated with no history of previous symptomatic COVID-19 infection. Seven individuals had previously been vaccinated with either one dose of Ad26.CoV2.S $(n=2)$ or two doses of BNT162b2 $(n=5)$ at least 56 days (56-163 days) prior to infection. Samples were taken a median of four days (1-10 days) after a positive PCR test. The median ages of the vaccinated individuals were similar to those of the unvaccinated group (58 and 64 respectively), and infections ranged from mild to severe as determined by WHO scoring (Table S1).

We first compared binding antibody levels, as measured by enzyme-linked immunosorbent assay (ELISA) against the ancestral D614G, Beta, Delta and Omicron spikes. In unvaccinated individuals, binding antibody titers against Omicron were highest, as expected, and were detectable in all donors. Although we observed statistically significant 2.2, 1.8 and 1.7-fold decreases in binding to D614G, Beta and Delta respectively in this group, Omicron-triggered antibodies were fairly cross-reactive for all variants tested, losing activity against other VOCs in $10-25 \%$ of individuals (Figure 1A, C). In previously vaccinated individuals who experienced breakthrough infection with Omicron, binding was substantially higher against Omicron than in unvaccinated individuals (geometric mean titer (GMT) of 2.92 versus 1.92) (Figure 1B, C). Furthermore, antibodies from these vaccinated individuals exhibited higher levels of crossreactivity against all variants, and no significant fold losses were observed (Figure 1B).

As spike binding antibodies perform Fc effector functions known to contribute to reduced disease severity and vaccine efficacy ${ }^{15,16}$, we examined antibody dependent cellular phagocytosis (ADCP) and antibody dependent cellular cytotoxicity (ADCC) in both groups. For unvaccinated individuals, ADCP against Omicron was detected in all 20 individuals with a geometric mean (GM) score of 32 (Figure 1D). Against VOCs, we observed less than two-fold reduction in activity across variants with $15 \%, 25 \%$ and $10 \%$ of individuals losing ADCP activity 
medRxiv preprint doi: https://doi.org/10.1101/2022.02.10.22270789; this version posted February 14, 2022. The copyright holder for this preprint (which was not certified by peer review) is the author/funder, who has granted medRxiv a license to display the preprint in It is made available under a CC-BY-NC-ND 4.0 International license .

against D614G, and Beta and Delta respectively. For vaccinated individuals, non-significant reductions against D614G, Beta and Delta were observed relative to Omicron and all donors exhibited activity against the panel of VOC tested here (Figure 1E). Compared to unvaccinated individuals, significantly higher levels of ADCP were observed in vaccinated individuals infected with Omicron, mirroring the binding antibodies (Figure 1E, F).

In contrast to binding and ADCP, ADCC in unvaccinated individuals showed significant losses against D614G (3-fold loss) and Beta (4-fold loss). However, like ADCP and binding antibodies, ADCC activity against Delta was retained (Figure 1G). In this group, Omicrontriggered $\mathrm{ADCC}$ was undetectable against $\mathrm{D} 614 \mathrm{G}$ and Beta in $25 \%$ and $30 \%$ of plasma samples, respectively. After previous vaccination, Omicron breakthrough infections resulted in overall preservation of ADCC against VOCs, with only one individual showing undetectable activity against Delta (Figure $1 \mathrm{H}$ ). Levels of ADCC in previously vaccinated donors were significantly higher than those in unvaccinated individuals, with the exception of Delta, where similar ADCC activity was observed in both groups (Figure 1I).

Lastly, we measured neutralizing antibody responses to Omicron, and assessed their crossreactivity for VOCs. In addition to those variants tested for Fc effector function, we also tested C.1.2, a variant with several neutralization evasive mutations, which circulated at low levels during the third and fourth COVID-19 waves in South Africa ${ }^{17}$. Against Omicron, unvaccinated individuals showed potent neutralization, with a GMT of 4,288 . However, against VOCs, we saw dramatic reductions of 27-, 43-, 23- and 20-fold in titer for D614G, Beta, C.1.2 and Delta, respectively, and knock out ranging from $27 \%$ to $45 \%$ of plasma tested (Figure $2 \mathrm{~A}$ ), particularly evident for Beta. This loss of neutralization was mitigated by prior vaccination, with all seven breakthrough infections resulting in a significantly increased GMT of 12,197 against Omicron, and high titers against all VOCs (25,263 for D614G; 2,913 for Beta; 4,506 against C.1.2 and 3004 against Delta) (Figure 2B, C). These greatly enhanced titers resulted in far greater fold increases between previously vaccinated individuals and unvaccinated individuals $(158,29$, 
medRxiv preprint doi: https://doi.org/10.1101/2022.02.10.22270789; this version posted February 14, 2022. The copyright holder for this preprint (which was not certified by peer review) is the author/funder, who has granted medRxiv a license to display the preprint in It is made available under a CC-BY-NC-ND 4.0 International license .

14 and 3-fold for D614G, Beta, Delta and Omicron respectively) compared to those seen for Fc effector functions and binding which ranged from 1 to 3 fold (Figure $1 \mathrm{C}, \mathrm{F}, \mathrm{I}$ ). Notably, Omicron infection elicited robust and similar neutralization titers against itself regardless of vaccination status.

While the neutralization resistance of Omicron is now well-defined, here we address the question of how effectively Omicron-elicited antibodies target D614G and other VOCs. We show that in previously unvaccinated individuals, Omicron-triggered antibodies bind and perform Fc effector function with only slight loss against VOCs. However, neutralization was significantly compromised against VOCs, indicating limited neutralization cross-reactivity of antibodies elicited by Omicron. In contrast, vaccinated individuals who subsequently became infected with Omicron, showed greatly improved cross-reactivity with high titers against Omicron, D614G (one amino acid different from the vaccine spike), Beta, Delta and C.1.2.

We and others have previously shown that Fc effector function is largely preserved against VOCs in both convalescent and vaccine-elicited plasma ${ }^{9,10}$. Also, as with neutralization, we have shown that Fc effector function triggered by Beta is substantially more cross-reactive compared to antibodies elicited by D614G, indicating that the spike sequence of the eliciting immunogen impacts the extent of ADCC cross-reactivity ${ }^{9,18}$. Here, we show that Omicron infection similarly triggers differential ADCC cross-reactivity, with significantly decreased activity against D614G and Beta, but not Delta. This observation extended to vaccinated individuals, where even boosted ADCC was still significantly poorer against Beta. This differential targeting of ADCC-mediating antibodies indicates that they may preferentially bind sites that differ between Omicron and other VOCs. Alternatively, different VOCs may trigger antibodies with varied glycosylations and isotype, both of which are known to modulate Fc effector function ${ }^{19}$. 
medRxiv preprint doi: https://doi.org/10.1101/2022.02.10.22270789; this version posted February 14, 2022. The copyright holder for this preprint (which was not certified by peer review) is the author/funder, who has granted medRxiv a license to display the preprint in It is made available under a CC-BY-NC-ND 4.0 International license .

This differential immune imprinting by VOCs was also confirmed for neutralization in this study in both unvaccinated and vaccinated Omicron-infected individuals. The highest titers in unvaccinated individuals were to the infection-matched Omicron. In contrast, in previously vaccinated individuals with breakthrough Omicron infections, high titers were observed against both $\mathrm{D} 614 \mathrm{G}$ and Omicron; sequences that match the vaccine and infecting spikes to which these donors have been exposed. This is consistent with our previous studies indicating that the sequence of the infecting spike impacts the quality of the neutralization, suggesting imprinting of the immune response $\mathrm{e}^{20}$.

We and others have shown that humoral function is significantly boosted in individuals with breakthrough infections after vaccination ${ }^{21-23}$. This study confirms that this is also true of Omicron breakthrough infections, with a 153-fold increase in titers to D614G in vaccinated compared to unvaccinated individuals, consistent with other studies ${ }^{23-25}$. We also extend our previous study, where we showed ADCC was boosted by breakthrough infection, to include ADCP, confirming that this applies to other Fc effector functions ${ }^{21}$.

In the absence of vaccination, Omicron-elicited humoral responses, while potent against the matched Omicron spike, show significantly less activity against VOCs. Thus, while highly immunogenic, Omicron does not elicit cross-neutralizing responses. This is consistent with a decrease in the ability of plasma from unvaccinated individuals to neutralize Delta compared to Omicron following Omicron infection ${ }^{25}$. This may result in risk of reinfection in this unvaccinated group with other variants that continued to circulate and evolve in South Africa at the time of this study, albeit at low levels including Beta, Delta and C.1.2.

Our data also have implications for the design of second-generation vaccines based on Omicron, suggesting that this may not trigger cross-reactive de novo responses in SARS-CoV2 naive individuals. This is supported by immunogenicity studies, where Delta-infected mice elicited broadly protective antibodies, but Omicron-infected mice failed to mount responses 
medRxiv preprint doi: https://doi.org/10.1101/2022.02.10.22270789; this version posted February 14, 2022. The copyright holder for this preprint (which was not certified by peer review) is the author/funder, who has granted medRxiv a license to display the preprint in It is made available under a CC-BY-NC-ND 4.0 International license .

against other $\mathrm{VOCs}^{23}$. In addition, immunization of mice with a receptor binding domain (RBD)based Omicron mRNA vaccine only elicited strain-specific neutralization ${ }^{26}$. In support of this study and others ${ }^{27}$, our data also suggests that Omicron is highly immunogenic, eliciting comparable neutralization titers irrespective of vaccination status but only in terms of a strainspecific response. Given the significant boost we see against Omicron in vaccinated individuals, Omicron boosters may be effective in seropositive individuals, a group that exceeds $70 \%$ in South Africa ${ }^{28}$. However, in a comparison of mRNA-1273 vaccinated rhesus macaques boosted with either mRNA-Omicron or mRNA-1273, Omicron boosted animals showed lower titers than those with a homologous mRNA-1273 boost ${ }^{29}$. Overall, these data suggest that boosting individuals with or without immunity with vaccines specific for Omicron is unlikely to be superior to existing regimens.

Our study is limited by the fact that we cannot rule out prior asymptomatic infection, and that viral sequences confirming Omicron infection are available only for a subset of samples. However, we note that Omicron overwhelmingly dominated infections during the wave in which these individuals were tested ${ }^{1}$. Further, the median age of individuals in this study is advanced (58 years) and may contribute to comprised cross-reactivity noted for unvaccinated individuals. Given the high prevalence of global seropositivity, through vaccination or previous infection, the ability to measure the response to Omicron infection in naive samples is limited. As such our study offers valuable insights into the usefulness of Omicron as an immunogen, the potential risk of reinfection in unvaccinated individuals, and the observation that crossreactive responses are greatly improved by vaccination.

\section{Acknowledgements}

We acknowledge the participants who volunteered for this study and thank $\mathrm{W}$ van Hougenhouck-Tulleken for database support. We thank Rajiev Ramlall for assistance with participant recruitment at Tshwane District Hospital and Daniel Amoako and Jennifer Giandhari for sequencing support. The parental soluble spike was provided by J McLellan 
medRxiv preprint doi: https://doi.org/10.1101/2022.02.10.22270789; this version posted February 14 , 2022. The copyright holder for this preprint (which was not certified by peer review) is the author/funder, who has granted medRxiv a license to display the preprint in It is made available under a CC-BY-NC-ND 4.0 International license

(University of Texas) and parental pseudovirus plasmids by Drs E Landais and D Sok (IAVI). PLM is supported by the South African Research Chairs Initiative of the Department of Science and Innovation and National Research Foundation of South Africa, the SA Medical Research Council SHIP program, the Centre for the AIDS Programme of Research in South Africa (CAPRISA). We acknowledge funding from the Bill and Melinda Gates Foundation, through the Global Immunology and Immune Sequencing for Epidemic Response (GIISER) program. SIR is a L'Oreal/UNESCO Women in Science South Africa Young Talents awardee.

\section{Author contributions}

S.I.R designed the study, performed experiments, analyzed the data and wrote the manuscript. N.P.M and H.S performed Fc experiments and analyzed data. V.S.M, N.M and T.M performed neutralization assays. B.E.L, B.O. and F.A. produced spikes and variant plasmids. F.A and Z.M performed ELISA assays supervised by T.M.G. M.A. vdM processed samples which were recruited by Z. dB., T.R d. V., A.B. and G.vdB. V.U, T.R. and M.T.B established the Pretoria COVID-19 study which provided participant samples from the Tshwane District Hospital. A.S, A.M, H.T., M.V., and TdO performed SARS-CoV-2 sequencing. PLM conceptualized the study and wrote the manuscript.

\section{Declaration of Interests}

All authors declare no competing interests. 
medRxiv preprint doi: https://doi.org/10.1101/2022.02.10.22270789; this version posted February 14, 2022. The copyright holder for this preprint (which was not certified by peer review) is the author/funder, who has granted medRxiv a license to display the preprint in It is made available under a CC-BY-NC-ND 4.0 International license

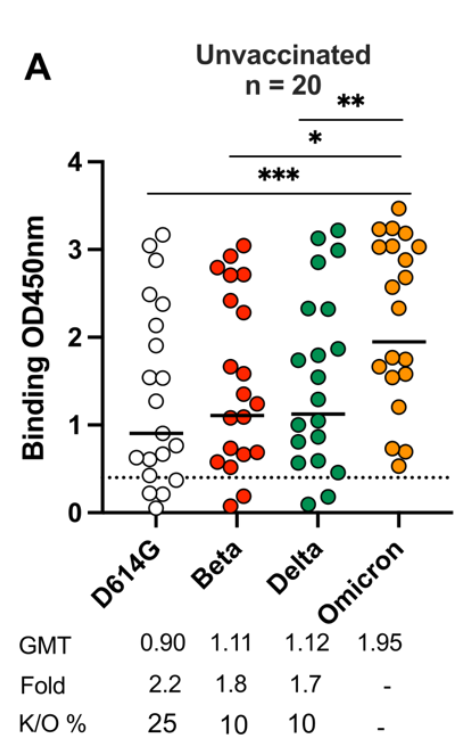

B Vaccinated

C
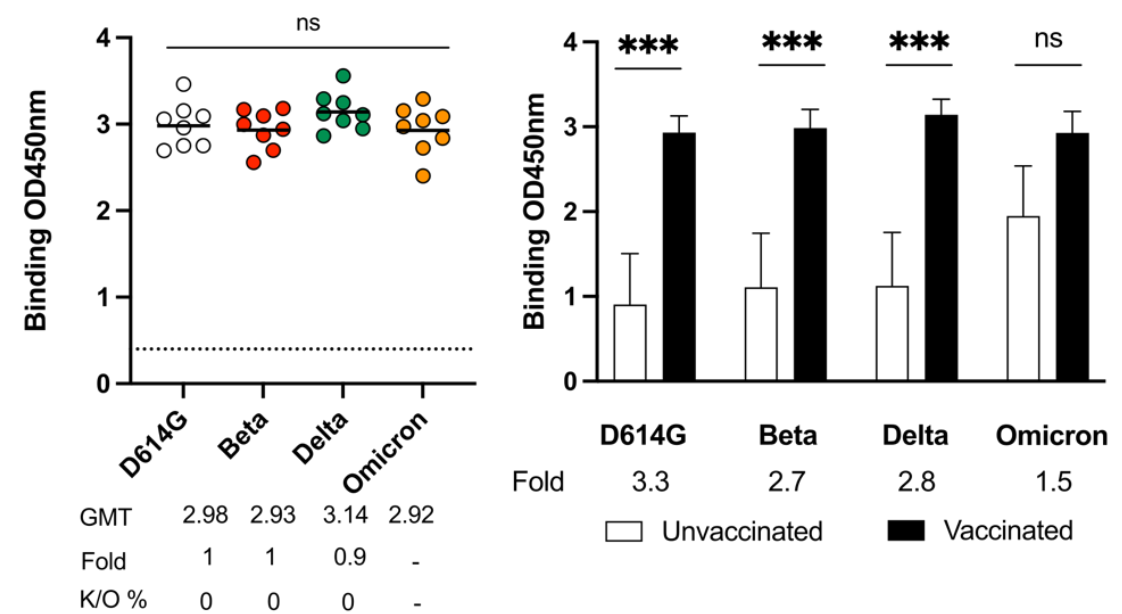

Antibody Dependent Cellular Phagocytosis (ADCP)

D Unvaccinated $\mathrm{n}=\mathbf{2 0}$
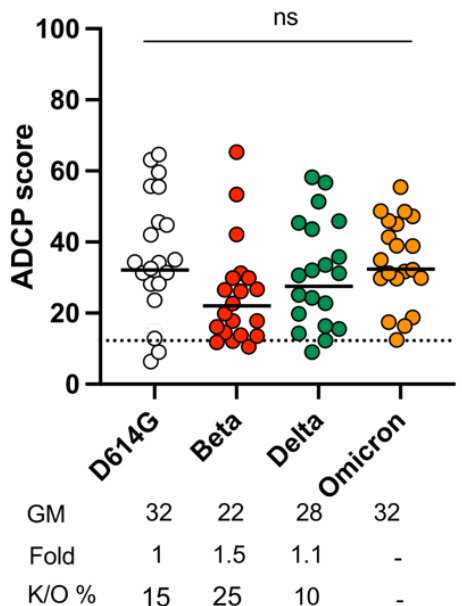

E

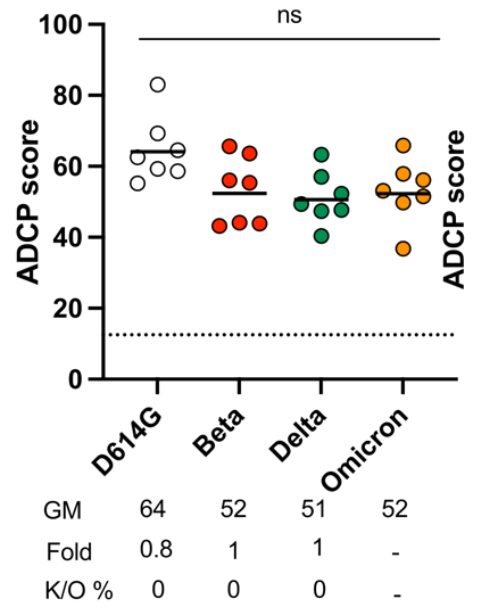

$F$

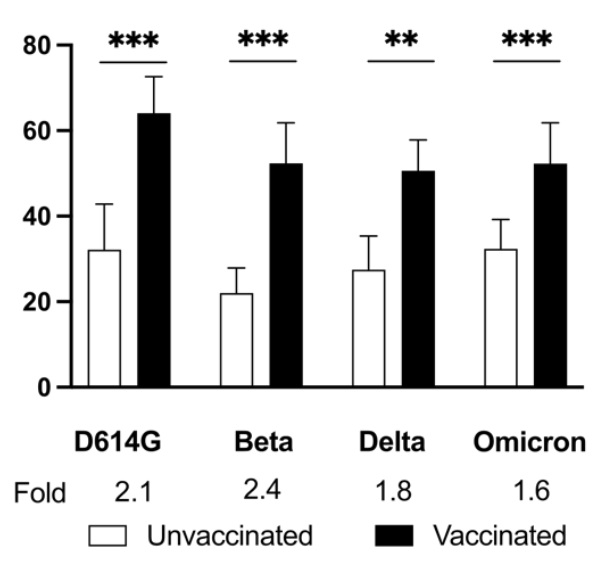

\section{Antibody Dependent Cellular Cytotoxicity (ADCC)}

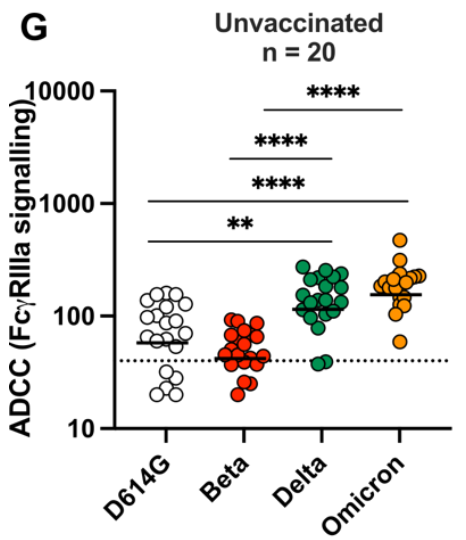

$\begin{array}{lllll}\text { GMT } & 68 & 49 & 135 & 183\end{array}$

$\begin{array}{lllll}\text { Fold } & 2.7 & 3.7 & 1.4\end{array}$

K/O \% $25 \quad 30 \quad 5$
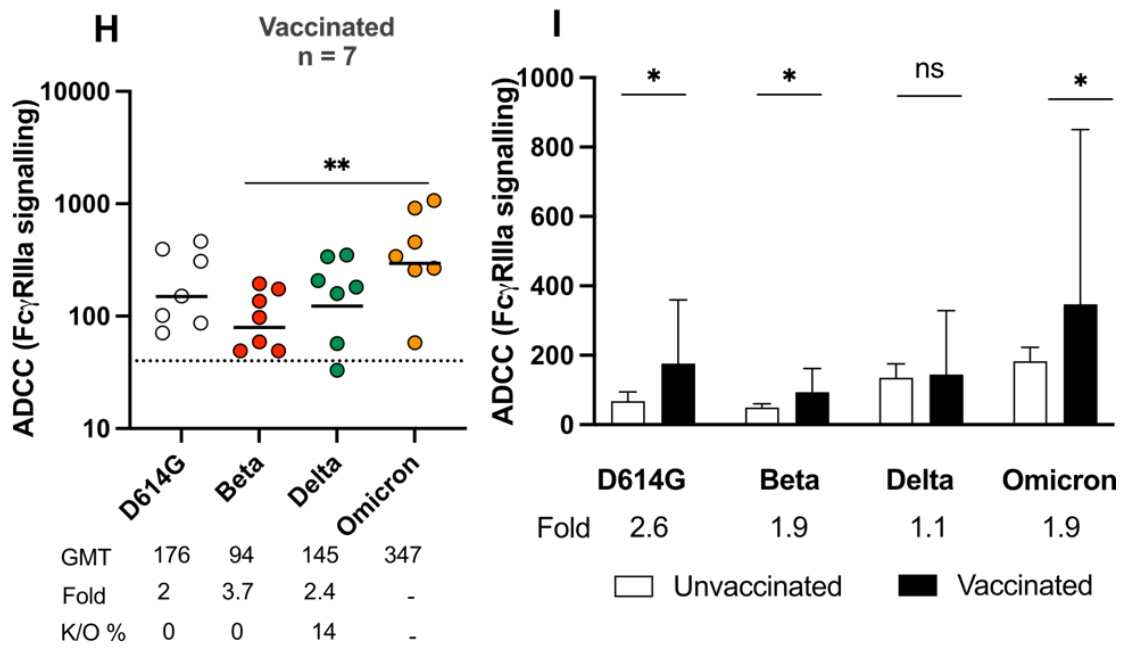
medRxiv preprint doi: https://doi.org/10.1101/2022.02.10.22270789; this version posted February 14, 2022. The copyright holder for this preprint (which was not certified by peer review) is the author/funder, who has granted medRxiv a license to display the preprint in It is made available under a CC-BY-NC-ND 4.0 International license .

Figure 1: Binding and Fc effector function elicited by Omicron infection is crossreactive against several variants of concern

Antibody binding measured by ELISA in $(A)$ unvaccinated individuals $(n=20)$ or $(B)$ individuals vaccinated with either one dose of Ad26.CoV.2S or two doses of BNT162b2 $(n=7)$ and infected by Omicron against D614G, Beta, Delta and Omicron spike proteins. (C) Bars show geometric mean binding titers for vaccinated (black) and unvaccinated (white) individuals against variants of concern. Antibody-dependent cellular phagocytosis (ADCP) of (D) unvaccinated and $(E)$ vaccinated individuals is represented as the percentage of monocytic cells that take up spike coated beads (D614G, Beta, Delta and Omicron) multiplied by their geometric mean fluorescence intensity (MFI). (F) Bars show geometric mean ADCP scores for vaccinated (black) and unvaccinated (white) individuals against variants of concern. Antibody dependent cellular cytotoxicity (ADCC) in $(G)$ unvaccinated and $(H)$ vaccinated individuals shown as relative light units (RLU) signaling through FcyRllla expressing cells. (I) Bars show geometric mean activity for vaccinated (black) and unvaccinated (white) individuals against variants of concern. All data are representative of two independent experiments. For dot plots, lines indicate geometric mean titer (GMT) also represented below the plot with fold decrease and knock-out $(\mathrm{K} / \mathrm{O})$ of activity for other variants as a percentage relative to Omicron. Dotted lines indicate the limit of detection of the particular assay. For bar charts, bars indicate median of function, with error bars showing standard deviations with fold decreases relative to vaccinated individuals indicated below the plot. Statistical significance across variants is shown by Friedman test with Dunn's correction and between vaccinated and unvaccinated samples by the Mann Whitney test. ${ }^{*} p<0.05 ;{ }^{* *} p<0.01 ;{ }^{* * *} p<0.001 ;{ }^{* * * *} p<0.0001$ and ns $=$ non-significant. 
A

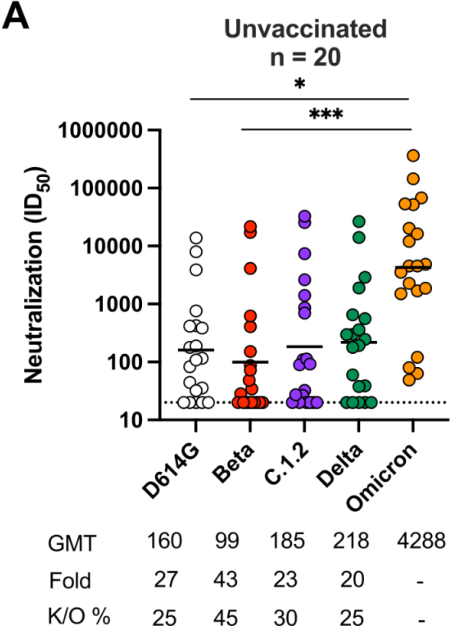

B

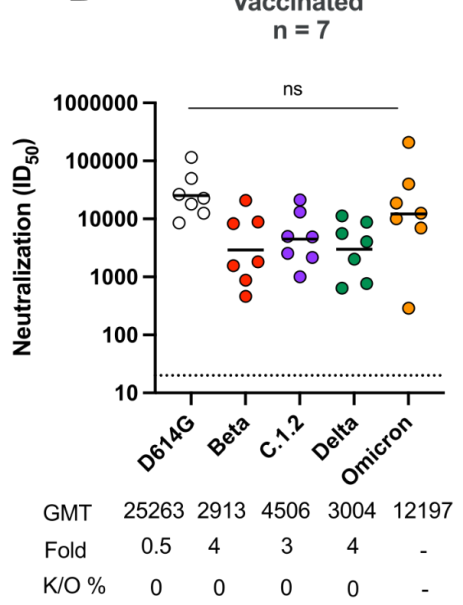

C

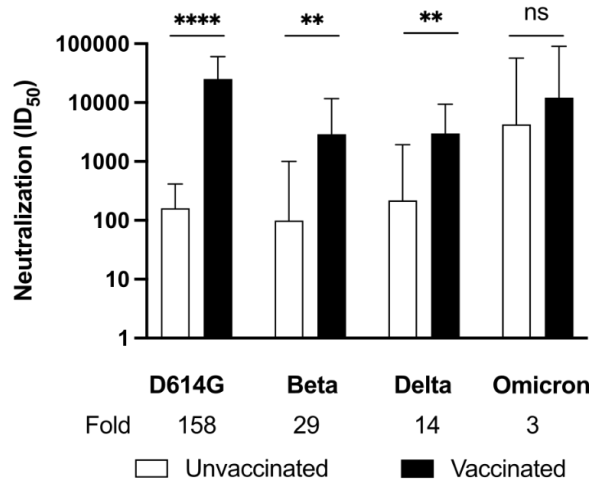

Figure 2: Omicron triggers cross-variant neutralizing antibodies which are broadened

\section{by vaccination}

Neutralization titer $\left(\mathrm{ID}_{50}\right)$ of Omicron-infected plasma against D614G, Beta, C.1.2, Delta and

Omicron pseudoviruses shown for $(A)$ unvaccinated individuals $(n=20)$ or $(B)$ individuals vaccinated with either one dose of Ad26.CoV.2S or two doses of BNT162b2 (n=7). Lines indicate geometric mean titer (GMT) also represented below the plot with fold decrease and knockout $(\mathrm{K} / \mathrm{O})$ of activity for other variants as a percentage relative to Omicron. Dotted lines indicate the limit of detection of the assay. Statistical significance across variants is shown by Friedman test with Dunns correction. (C) Bars show geometric mean neutralization titers for vaccinated (black) and unvaccinated (white) individuals against variants of concern with error bars showing standard deviations with fold decreases relative to vaccinated individuals indicated below the plot. Statistical significance between vaccinated and unvaccinated samples by the Mann Whitney test. ${ }^{*} p<0.05 ;{ }^{* *} p<0.01 ;{ }^{* * *} p<0.001 ;{ }^{* * * *} p<0.0001$ and $n s=$ non-significant. All data are representative of two independent experiments. 
medRxiv preprint doi: https://doi.org/10.1101/2022.02.10.22270789; this version posted February 14, 2022. The copyright holder for this preprint (which was not certified by peer review) is the author/funder, who has granted medRxiv a license to display the preprint in

It is made available under a CC-BY-NC-ND 4.0 International license .

Table S1: Demographic and clinical description of the cohort

\begin{tabular}{|c|c|c|c|c|c|c|c|}
\hline Study number & Age & Gender & Days sampled post infection & Vaccination status & Days since vaccination & Sequence & Severity \\
\hline COV132 & $36-40$ & Male & 9 & Unvaccinated & - & Not sequenced & Severe \\
\hline COV140 & $26-30$ & Female & 1 & Unvaccinated & - & Not sequenced & Mild \\
\hline COV145 & $16-20$ & Female & 3 & Unvaccinated & - & Omicron & Mild \\
\hline COV149 & $60-65$ & Female & 3 & Unvaccinated & - & Not sequenced & Mild \\
\hline COV157 & $66-70$ & Male & 4 & Unvaccinated & - & Omicron & Moderate \\
\hline COV158 & 66-70 & Female & 6 & Unvaccinated & - & Not sequenced & Moderate \\
\hline COV159 & $20-25$ & Male & 6 & Unvaccinated & - & Not sequenced & Mild \\
\hline COV162 & $56-60$ & Male & 5 & Unvaccinated & - & Not sequenced & Moderate \\
\hline COV165 & $60-65$ & Female & 4 & Unvaccinated & - & Not sequenced & Moderate \\
\hline COV166 & $56-60$ & Male & 4 & Unvaccinated & - & Not sequenced & Severe \\
\hline COV167 & $60-65$ & Female & 8 & Unvaccinated & - & Not sequenced & Severe \\
\hline COV176 & $70-75$ & Male & 2 & Unvaccinated & - & Not sequenced & Moderate \\
\hline COV178 & $60-65$ & Female & 2 & Unvaccinated & - & Omicron & Moderate \\
\hline COV183 & $26-30$ & Male & 2 & Unvaccinated & - & Not sequenced & Mild \\
\hline COV184 & $56-60$ & Male & 1 & Unvaccinated & - & Not sequenced & Moderate \\
\hline COV185 & $46-50$ & Female & 1 & Unvaccinated & - & Not sequenced & Moderate \\
\hline COV186 & $56-60$ & Male & 10 & Unvaccinated & - & Omicron & Moderate \\
\hline COV187 & $30-35$ & Female & 3 & Unvaccinated & - & Not sequenced & Mild \\
\hline COV189 & $46-50$ & Male & 5 & Unvaccinated & - & Not sequenced & Moderate \\
\hline COV190 & $30-35$ & Female & 4 & Unvaccinated & - & Omicron & Mild \\
\hline COV151 & $46-50$ & Male & 1 & One dose Ad26.CoV2.S & 56 & Omicron & Severe \\
\hline COV182 & $36-40$ & Male & 3 & One dose Ad26.CoV2.S & Unknown & Not sequenced & Mild \\
\hline COV131 & $56-60$ & Female & 4 & Two doses BNT162b2 & 109 & Not sequenced & Severe \\
\hline Cov135 & $80-85$ & Male & 5 & Two doses BNT162b2 & 72 & Omicron & Mild \\
\hline COV138 & $66-70$ & Male & 5 & Two doses BNT162b2 & Unknown & Not sequenced & Moderate \\
\hline Cov161 & $60-65$ & Female & 5 & Two doses BNT162b2 & 112 & Not sequenced & Mild \\
\hline Cov181 & $70-75$ & Male & 4 & Two doses BNT162b2 & 163 & Not sequenced & Severe \\
\hline
\end{tabular}

\section{References}

1. Viana R, Moyo S, Amoako DG, Tegally H, Scheepers C, Althaus CL, et al. Rapid epidemic expansion of the SARS-CoV-2 Omicron variant in southern Africa. Nature [Internet]. 2022; Available from: https://doi.org/10.1038/s41586-022-04411-y

2. Sievers BL, Chakraborty S, Xue Y, Gelbart T, Gonzalez JC, Cassidy AG, et al. Antibodies elicited by SARS-CoV-2 infection or mRNA vaccines have reduced neutralizing activity against Beta and Omicron pseudoviruses. Sci Transl Med [Internet]. 2022 Jan 13;0(0):eabn7842. Available from:

https://doi.org/10.1126/scitranslmed.abn7842

3. Schmidt F, Muecksch F, Weisblum Y, Da Silva J, Bednarski E, Cho A, et al. Plasma Neutralization of the SARS-CoV-2 Omicron Variant. N Engl J Med [Internet]. 2021

Dec 30; Available from: https://doi.org/10.1056/NEJMc2119641

4. Cele S, Jackson L, Khoury DS, Khan K, Moyo-Gwete T, Tegally H, et al. Omicron extensively but incompletely escapes Pfizer BNT162b2 neutralization. Nature [Internet]. 2021 Dec 23; Available from: https://doi.org/10.1038/s41586-021-04387-1

5. Garcia-Beltran WF, St. Denis KJ, Hoelzemer A, Lam EC, Nitido AD, Sheehan ML, et al. mRNA-based COVID-19 vaccine boosters induce neutralizing immunity against SARS-CoV-2 Omicron variant. Cell [Internet]. 2022;185(3):457-466.e4. Available from: https://www.sciencedirect.com/science/article/pii/S0092867421014963

6. Carreño JM, Alshammary H, Tcheou J, Singh G, Raskin A, Kawabata H, et al. Activity 
medRxiv preprint doi: https://doi.org/10.1101/2022.02.10.22270789; this version posted February 14, 2022. The copyright holder for this preprint (which was not certified by peer review) is the author/funder, who has granted medRxiv a license to display the preprint in It is made available under a CC-BY-NC-ND 4.0 International license .

of convalescent and vaccine serum against SARS-CoV-2 Omicron. Nature [Internet]. 2021 Dec 31; Available from: https://doi.org/10.1038/s41586-022-04399-5

7. Wibmer CK, Ayres F, Hermanus T, Madzivhandila M, Kgagudi P, Oosthuysen B, et al. SARS-CoV-2 501Y.V2 escapes neutralization by South African COVID-19 donor plasma. Nat Med [Internet]. 2021; Available from: https://doi.org/10.1038/s41591-02101285-x

8. Bartsch Y, Tong X, Kang J, Avendaño MJ, Serrano EF, García-Salum T, et al. Preserved Omicron Spike specific antibody binding and Fc-recognition across COVID19 vaccine platforms. medRxiv [Internet]. 2021 Jan 1;2021.12.24.21268378. Available from: http://medrxiv.org/content/early/2021/12/27/2021.12.24.21268378.abstract

9. Richardson SI, Manamela NP, Motsoeneng BM, Kaldine H, Ayres F, Makhado Z, et al. SARS-CoV-2 Beta and Delta variants trigger Fc effector function with increased cross-reactivity. Cell Reports Med [Internet]. 2022 Jan 6;100510. Available from: https://doi.org/10.1016/j.xcrm.2022.100510

10. Kaplonek P, Fischinger S, Cizmeci D, Bartsch YC, Kang J, Burke JS, et al. mRNA1273 vaccine-induced antibodies maintain Fc effector functions across SARS-CoV-2 variants of concern. Immunity [Internet]. 2022 Jan 6;S1074-7613(22)00030-9. Available from: https://pubmed.ncbi.nlm.nih.gov/35090580

11. Keeton R, Tincho MB, Ngomti A, Baguma R, Benede N, Suzuki A, et al. T cell responses to SARS-CoV-2 spike cross-recognize Omicron. Nature [Internet]. 2022 Jan 31; Available from: https://doi.org/10.1038/s41586-022-04460-3

12. Gao Y, Cai C, Grifoni A, Müller TR, Niessl J, Olofsson A, et al. Ancestral SARS-CoV2-specific T cells cross-recognize the Omicron variant. Nat Med [Internet]. 2022 Jan 14; Available from: https://doi.org/10.1038/s41591-022-01700-x

13. Tarke A, Coelho CH, Zhang Z, Dan JM, Yu ED, Methot N, et al. SARS-CoV-2 vaccination induces immunological T cell memory able to cross-recognize variants from Alpha to Omicron. Cell [Internet]. 2022 Jan 6; Available from: https://doi.org/10.1016/j.cell.2022.01.015

14. Collie S, Champion J, Moultrie H, Bekker L-G, Gray G. Effectiveness of BNT162b2 Vaccine against Omicron Variant in South Africa. N Engl J Med [Internet]. 2022 Feb 3;386(5):494-6. Available from: https://doi.org/10.1056/NEJMc2119270

15. Yu J, Tostanoski LH, Peter L, Mercado NB, McMahan K, Mahrokhian SH, et al. DNA vaccine protection against SARS-CoV-2 in rhesus macaques. Science (80- ) [Internet]. 2020 Aug 14;369(6505):806-11. Available from: https://www.sciencemag.org/lookup/doi/10.1126/science.abc6284

16. Zohar T, Loos C, Fischinger S, Atyeo C, Wang C, Slein MD, et al. Compromised Humoral Functional Evolution Tracks with SARS-CoV-2 Mortality. Cell [Internet]. 2020 
medRxiv preprint doi: https://doi.org/10.1101/2022.02.10.22270789; this version posted February 14, 2022. The copyright holder for this preprint (which was not certified by peer review) is the author/funder, who has granted medRxiv a license to display the preprint in It is made available under a CC-BY-NC-ND 4.0 International license .

Dec;183(6):1508-1519.e12. Available from: https://doi.org/10.1016/j.cell.2020.10.052

17. Scheepers C, Everatt J, Amoako DG, Tegally H, Wibmer CK, Mnguni A, et al.

Emergence and phenotypic characterization of C.1.2, a globally detected lineage that rapidly accumulated mutations of concern. medRxiv [Internet]. 2021 Jan 1;2021.08.20.21262342. Available from:

http://medrxiv.org/content/early/2021/09/24/2021.08.20.21262342.abstract

18. Moyo-Gwete T, Madzivhandila M, Makhado Z, Ayres F, Mhlanga D, Oosthuysen B, et al. Cross-Reactive Neutralizing Antibody Responses Elicited by SARS-CoV-2 501Y.V2 (B.1.351). N Engl J Med [Internet]. 2021 Apr 7;384(22):2161-3. Available from: https://doi.org/10.1056/NEJMc2104192

19. Jennewein MF, Alter G. The Immunoregulatory Roles of Antibody Glycosylation. Trends Immunol [Internet]. 2017 May;38(5):358-72. Available from: https://linkinghub.elsevier.com/retrieve/pii/S1471490617300273

20. Keeton R, Richardson SI, Moyo-Gwete T, Hermanus T, Tincho MB, Benede N, et al. Prior infection with SARS-CoV-2 boosts and broadens Ad26.COV2.S immunogenicity in a variant-dependent manner. Cell Host Microbe [Internet]. 2021;29(11):16111619.e5. Available from: https://doi.org/10.1016/j.chom.2021.10.003

21. Kitchin D, Richardson SI, van der Mescht MA, Motlou T, Mzindle N, Moyo-Gwete T, et al. Ad26.COV2.S breakthrough infections induce high titers of neutralizing antibodies against Omicron and other SARS-CoV-2 variants of concern. medRxiv [Internet]. 2022 Jan 1;2021.11.08.21266049. Available from:

http://medrxiv.org/content/early/2022/01/04/2021.11.08.21266049.abstract

22. Walls AC, Sprouse KR, Bowen JE, Joshi A, Franko N, Navarro MJ, et al. SARS-CoV2 breakthrough infections elicit potent, broad, and durable neutralizing antibody responses. Cell [Internet]. 2022 Jan; Available from: https://www.sciencedirect.com/science/article/pii/S0092867422000691

23. Suryawanshi RK, Chen IP, Ma T, Syed AM, Simoneau CR, Ciling A, et al. Limited cross-variant immunity after infection with the SARS-CoV-2 Omicron variant without vaccination. medRxiv [Internet]. 2022 Jan 1;2022.01.13.22269243. Available from: http://medrxiv.org/content/early/2022/01/17/2022.01.13.22269243.abstract

24. Zhou R, To KK-W, Peng Q, Chan JM-C, Huang H, Yang D, et al. Vaccinebreakthrough infection by the SARS-CoV-2 omicron variant elicits broadly crossreactive immune responses. Clin Transl Med [Internet]. 2022 Jan 26;12(1):e720e720. Available from: https://pubmed.ncbi.nlm.nih.gov/35083867

25. Khan K, Karim F, Cele S, San JE, Lustig G, Tegally H, et al. Omicron infection of vaccinated individuals enhances neutralizing immunity against the Delta variant. medRxiv [Internet]. 2022 Jan 1;2021.12.27.21268439. Available from: 
medRxiv preprint doi: https://doi.org/10.1101/2022.02.10.22270789; this version posted February 14, 2022. The copyright holder for this preprint (which was not certified by peer review) is the author/funder, who has granted medRxiv a license to display the preprint in It is made available under a CC-BY-NC-ND 4.0 International license .

http://medrxiv.org/content/early/2022/01/28/2021.12.27.21268439.abstract

26. Lee I-J, Sun C-P, Wu P-Y, Lan Y-H, Wang I-H, Liu W-C, et al. Omicron-specific mRNA vaccine induced potent neutralizing antibody against Omicron but not other SARS-CoV-2 variants. bioRxiv [Internet]. 2022 Jan 1;2022.01.31.478406. Available from: http://biorxiv.org/content/early/2022/01/31/2022.01.31.478406.abstract

27. Hawman DW, Meade-White K, Clancy C, Archer J, Hinkley T, Leventhal SS, et al. Replicating RNA platform enables rapid response to the SARS-CoV-2 Omicron variant and elicits enhanced protection in naïve hamsters compared to ancestral vaccine. bioRxiv [Internet]. 2022 Jan 1;2022.01.31.478520. Available from: http://biorxiv.org/content/early/2022/02/03/2022.01.31.478520.abstract

28. Madhi SA, Kwatra G, Myers JE, Jassat W, Dhar N, Mukendi CK, et al. South African Population Immunity and Severe Covid-19 with Omicron Variant. medRxiv [Internet]. 2022 Jan 1;2021.12.20.21268096. Available from:

http://medrxiv.org/content/early/2022/01/27/2021.12.20.21268096.abstract

29. Gagne M, Moliva JI, Foulds KE, Andrew SF, Flynn BJ, Werner AP, et al. mRNA-1273 or mRNA-Omicron boost in vaccinated macaques elicits comparable $B$ cell expansion, neutralizing antibodies and protection against Omicron. bioRxiv [Internet]. 2022 Jan 1;2022.02.03.479037. Available from:

http://biorxiv.org/content/early/2022/02/04/2022.02.03.479037.abstract

30. Tegally H, Wilkinson E, Giovanetti M, Iranzadeh A, Fonseca V, Giandhari J, et al. Detection of a SARS-CoV-2 variant of concern in South Africa. Nature [Internet]. 2021;592(7854):438-43. Available from: https://doi.org/10.1038/s41586-021-03402-9

31. Hadfield J, Megill C, Bell SM, Huddleston J, Potter B, Callender C, et al. Nextstrain: real-time tracking of pathogen evolution. Bioinformatics [Internet]. $2018 \mathrm{Dec}$ 1;34(23):4121-3. Available from: https://doi.org/10.1093/bioinformatics/bty407

32. Ackerman ME, Moldt B, Wyatt RT, Dugast A-S, McAndrew E, Tsoukas S, et al. A robust, high-throughput assay to determine the phagocytic activity of clinical antibody samples. J Immunol Methods [Internet]. 2011 Mar;366(1-2):8-19. Available from: https://linkinghub.elsevier.com/retrieve/pii/S0022175910003935

\section{Methods}

\section{RESOURCE AVAILABILITY}

\section{Lead Contact}

Further information and reasonable requests for resources and reagents should be directed to and will be fulfilled by the lead contact, Penny Moore (pennym@nicd.ac.za). 
medRxiv preprint doi: https://doi.org/10.1101/2022.02.10.22270789; this version posted February 14 , 2022. The copyright holder for this preprint (which was not certified by peer review) is the author/funder, who has granted medRxiv a license to display the preprint in It is made available under a CC-BY-NC-ND 4.0 International license .

\section{Materials availability}

Materials will be made by request to Penny Moore (pennym@nicd.ac.za).

\section{Data and code availability}

All data reported in this paper will be shared by the lead contact upon request.

This paper does not report original code.

Any additional information required to reanalyze the data reported in this paper is available from the Lead Contact upon request.

\section{EXPERIMENTAL MODEL AND SUBJECT DETAILS}

\section{Human Subjects}

Samples infected in the fourth COVID-19 wave of infection in South Africa were collected from participants enrolled to the Pretoria COVID-19 study cohort. Participants were admitted to Tshwane District Hospital (Pretoria, South Africa) with mild to severe PCR confirmed SARSCoV-2 infection between 25 November 2021- 20 December 2021 (Table S1). Ethics approval was received from the University of Pretoria, Human Research Ethics Committee (Medical) (247/2020). All patients had PCR confirmed SARS-CoV-2 infection before blood collection which was done a median of 4 days post positive PCR test. Written informed consent was obtained from all participants.

\section{Cell lines}

Human embryo kidney HEK293T cells were cultured at $37^{\circ} \mathrm{C}, 5 \% \mathrm{CO}$, in DMEM containing $10 \%$ heat-inactivated fetal bovine serum (Gibco BRL Life Technologies) and supplemented with $50 \mu \mathrm{g} / \mathrm{ml}$ gentamicin (Sigma). Cells were disrupted at confluence with $0.25 \%$ trypsin in 1 mM EDTA (Sigma) every 48-72 hours. HEK293T/ACE2.MF cells were maintained in the same way as HEK293T cells but were supplemented with $3 \mu \mathrm{g} / \mathrm{ml}$ puromycin for selection of stably transduced cells. HEK293F suspension cells were cultured in 293 Freestyle media (Gibco BRL Life Technologies) and cultured in a shaking incubator at $37^{\circ} \mathrm{C}, 5 \% \mathrm{CO}, 70 \%$ humidity at 125rpm maintained between 0.2 and 0.5 million cells $/ \mathrm{ml}$. Jurkat-Lucia ${ }^{\text {TM }}$ NFAT-CD16 cells 
medRxiv preprint doi: https://doi.org/10.1101/2022.02.10.22270789; this version posted February 14, 2022. The copyright holder for this preprint (which was not certified by peer review) is the author/funder, who has granted medRxiv a license to display the preprint in It is made available under a CC-BY-NC-ND 4.0 International license .

were maintained in IMDM media with 10\% heat-inactivated fetal bovine serum (Gibco, Gaithersburg, MD), 1\% Penicillin Streptomycin (Gibco, Gaithersburg, MD) and $10 \mu \mathrm{g} / \mathrm{ml}$ of Blasticidin and $100 \mu \mathrm{g} / \mathrm{ml}$ of Zeocin was added to the growth medium every other passage. THP-1 cells were used for both the ADCP and ADCT assays and obtained from the AIDS Reagent Program, Division of AIDS, NIAID, NIH contributed by Dr. Li Wu and Vineet N. KewalRamani. Cells were cultured at $37^{\circ} \mathrm{C}, 5 \% \mathrm{CO} 2$ in RPMI containing $10 \%$ heat-inactivated fetal bovine serum (Gibco, Gaithersburg, MD) with 1\% Penicillin Streptomycin (Gibco, Gaithersburg, MD) and 2-mercaptoethanol to a final concentration of $0.05 \mathrm{mM}$ and not allowed to exceed $4 \times 10^{5}$ cells $/ \mathrm{ml}$ to prevent differentiation.

\section{METHOD DETAILS}

\section{SARS-CoV-2 spike genome sequencing}

Sequencing of the spike was performed as previously described ${ }^{30}$ using swabs obtained from Tshwane District Hospital patients of which 6 were available and confirmed to be Omicron (Table S1). RNA sequencing was performed as previously published. Briefly, extracted RNA was used to synthesize cDNA using the Superscript IV First Strand synthesis system (Life Technologies, Carlsbad, CA) and random hexamer primers. SARS-CoV-2 whole genome amplification was performed by multiplex PCR using primers designed on Primal Scheme (http://primal.zibraproject.org/) to generate 400 bp amplicons with a 70 bp overlap covering the SARS-CoV-2 genome. Phylogenetic clade classification of the genomes in this study consisted of analyzing them against a global reference dataset using a custom pipeline based on a local version of NextStrain (https://github.com/nextstrain/ncov) ${ }^{31}$.

\section{SARS-CoV-2 antigens}

For ELISA and ADCP assays, SARS-CoV-2 original and Beta variant full spike (L18F, D80A, D215G, K417N, E484K, N501Y, D614G, A701V, 242-244 del), Delta (T19R, 156-157del, R158G, L452R, T478K, D614G, P681R and D950N) and Omicron (A67V, $469-70$, T95I, G142D, $\Delta 143-145, \Delta 211$, L212I, 214EPE, G339D, S371L, S373P, S375F, K417N, N440K, 
medRxiv preprint doi: https://doi.org/10.1101/2022.02.10.22270789; this version posted February 14, 2022. The copyright holder for this preprint (which was not certified by peer review) is the author/funder, who has granted medRxiv a license to display the preprint in It is made available under a CC-BY-NC-ND 4.0 International license .

G446S, S477N, T478K, E484A, Q493R, G496S, Q498R, N501Y, Y505H, T547K, D614G, H655Y, N679K, P681H, N764K, D796Y, N856K, Q954H, N969K, L981F) proteins were expressed in Human Embryonic Kidney (HEK) 293F suspension cells by transfecting the cells with the respective expression plasmid. After incubating for six days at $37^{\circ} \mathrm{C}, 70 \%$ humidity and $10 \% \mathrm{CO}_{2}$, proteins were first purified using a nickel resin followed by size-exclusion chromatography. Relevant fractions were collected and frozen at $-80^{\circ} \mathrm{C}$ until use.

\section{SARS-CoV-2 Spike Enzyme-linked immunosorbent assay (ELISA)}

Two $\mu \mathrm{g} / \mathrm{ml}$ of spike protein (D614G, Beta, Delta or Omicron) was used to coat 96-well, highbinding plates and incubated overnight at $4{ }^{\circ} \mathrm{C}$. The plates were incubated in a blocking buffer consisting of $5 \%$ skimmed milk powder, $0.05 \%$ Tween 20 , 1x PBS. Plasma samples were diluted to $1: 100$ starting dilution in a blocking buffer and added to the plates. IgG secondary antibody was diluted to 1:3000 in blocking buffer and added to the plates followed by TMB substrate (Thermofisher Scientific). Upon stopping the reaction with $1 \mathrm{M} \mathrm{H}_{2} \mathrm{SO}_{4}$, absorbance was measured at a 450nm wavelength. In all instances, mAbs CR3022 and BD23 were used as positive controls and Palivizumab was used as a negative control.

\section{Spike plasmid and Lentiviral Pseudovirus Production}

The SARS-CoV-2 Wuhan-1 spike, cloned into pCDNA3.1 was mutated using the QuikChange Lightning Site-Directed Mutagenesis kit (Agilent Technologies) and NEBuilder HiFi DNA Assembly Master Mix (NEB) to include D614G (original) or lineage defining mutations for Beta (L18F, D80A, D215G, 242-244del, K417N, E484K, N501Y, D614G and A701V), Delta (T19R, 156-157del, R158G, L452R, T478K, D614G, P681R and D950N), C.1.2. (P9L, P25L, C136F, $\Delta 144, \mathrm{R} 190 \mathrm{~S}, \mathrm{D} 215 \mathrm{G}, \Delta 242-243, \mathrm{Y449H}, \mathrm{E} 484 \mathrm{~K}, \mathrm{~N} 501 \mathrm{Y}, \mathrm{L} 585 \mathrm{~F}, \mathrm{D} 614 \mathrm{G}, \mathrm{H655Y}, \mathrm{N679K}$, T716I, T859N) or Omicron (A67V, $\Delta 69-70$, T95I, G142D, $\Delta 143-145, \Delta 211$, L212I, 214EPE, G339D, S371L, S373P, S375F, K417N, N440K, G446S, S477N, T478K, E484A, Q493R, G496S, Q498R, N501Y, Y505H, T547K, D614G, H655Y, N679K, P681H, N764K, D796Y, N856K, Q954H, N969K, L981F). 
medRxiv preprint doi: https://doi.org/10.1101/2022.02.10.22270789; this version posted February 14, 2022. The copyright holder for this preprint (which was not certified by peer review) is the author/funder, who has granted medRxiv a license to display the preprint in It is made available under a CC-BY-NC-ND 4.0 International license .

Pseudotyped lentiviruses were prepared by co-transfecting HEK293T cell line with the SARSCoV-2 ancestral variant spike (D614G), Beta, Delta, C.1.2 or Omicron spike plasmids in conjunction with a firefly luciferase encoding lentivirus backbone plasmid as previously described $^{7}$. Briefly, pseudoviruses were produced by co-transfection in $293 T / 17$ cells with a lentiviral backbone (HIV-1 pNL4.luc encoding the firefly luciferase gene) and either of the SARS-CoV-2 spike plasmids with PEIMAX (Polysciences). Culture supernatants were clarified of cells by a $0.45-\mu \mathrm{M}$ filter and stored at $-70{ }^{\circ} \mathrm{C}$. Other pcDNA plasmids were used for the ADCC assay.

\section{Pseudovirus neutralization assay}

For the neutralization assay, plasma samples were heat-inactivated and clarified by centrifugation. Heat-inactivated plasma samples from vaccine recipients were incubated with the SARS-CoV-2 pseudotyped virus for 1 hour at $37^{\circ} \mathrm{C}, 5 \% \mathrm{CO} 2$. Subsequently, $1 \times 10^{4}$ HEK293T cells engineered to over-express ACE-2 (293T/ACE2.MF)(kindly provided by M. Farzan (Scripps Research)) were added and incubated at $37^{\circ} \mathrm{C}, 5 \% \mathrm{CO}_{2}$ for 72 hours upon which the luminescence of the luciferase gene was measured. Titers were calculated as the reciprocal plasma dilution $\left(\mathrm{ID}_{50}\right)$ causing $50 \%$ reduction of relative light units. $\mathrm{CB} 6$ and $\mathrm{CA} 1$ was used as positive controls for D614G, Beta and Delta. 084-7D, a mAb targeting K417N was used as a positive control for Omicron and Beta.

\section{Antibody-dependent cellular phagocytosis (ADCP) assay}

Avitagged SARS-CoV-2 spikes were biotinylated using the BirA biotin-protein ligase standard reaction kit (Avidity, LLC) and coated onto fluorescent neutravidin beads as previously described $^{32}$. Briefly, beads were incubated for two hours with monoclonal antibodies at a starting concentration of $20 \mu \mathrm{g} / \mathrm{ml}$ or plasma at a single 1 in 100 dilution. Opsonized beads were incubated with the monocytic THP-1 cell line overnight, fixed and interrogated on the 
medRxiv preprint doi: https://doi.org/10.1101/2022.02.10.22270789; this version posted February 14, 2022. The copyright holder for this preprint (which was not certified by peer review) is the author/funder, who has granted medRxiv a license to display the preprint in It is made available under a CC-BY-NC-ND 4.0 International license .

FACSAria II. Phagocytosis score was calculated as the percentage of THP-1 cells that engulfed fluorescent beads multiplied by the geometric mean fluorescence intensity of the population less the no antibody control. For this and all subsequent Fc effector assays, pooled plasma from 5 PCR-confirmed SARS-CoV-2 infected individuals and CR3022 were used as positive controls and plasma from 5 pre-pandemic healthy controls and Palivizumab were used as negative controls. In addition samples both waves were run head-to-head in the same experiment. ADCP scores for different spikes were normalised to each other and between runs using CR3022.

\section{Antibody-dependent cellular cytotoxicity (ADCC) assay}

The ability of plasma antibodies to cross-link and signal through FcyRIIla (CD16) and spike expressing cells or SARS-CoV-2 protein was measured as a proxy for ADCC. For spike assays, HEK293T cells were transfected with $5 \mu \mathrm{g}$ of SARS-CoV-2 spike plasmids using PEIMAX 40,000 (Polysciences) and incubated for 2 days at $37^{\circ} \mathrm{C}$. Expression of spike was confirmed by differential binding of CR3022 and P2B-2F6 and their detection by anti-IgG APC staining measured by flow cytometry. Subsequently, $1 \times 10^{5}$ spike transfected cells per well were incubated with heat inactivated plasma (1:100 final dilution) or monoclonal antibodies (final concentration of $100 \mu \mathrm{g} / \mathrm{ml}$ ) in RPMl 1640 media supplemented with $10 \%$ FBS $1 \%$ Pen/Strep (Gibco, Gaithersburg, MD) for 1 hour at $37^{\circ} \mathrm{C}$. Jurkat-Lucia ${ }^{\mathrm{TM}}$ NFAT-CD16 cells (Invivogen) $\left(2 \times 10^{5}\right.$ cells/well and $1 \times 10^{5}$ cells/well for spike and other protein respectively) were added and incubated for 24 hours at $37^{\circ} \mathrm{C}, 5 \% \mathrm{CO}_{2}$. Twenty $\mu$ of supernatant was then transferred to a white 96 -well plate with $50 \mu$ l of reconstituted QUANTI-Luc secreted luciferase and read immediately on a Victor 3 luminometer with 1s integration time. Relative light units (RLU) of a no antibody control was subtracted as background. Palivizumab was used as a negative control, while CR3022 was used as a positive control, and P2B-2F6 to differentiate the Beta from the D614G variant. 084-7D was used as a positive control for Omicron and Beta. To induce the transgene $1 \mathrm{x}$ cell stimulation cocktail (Thermofisher Scientific, Oslo, Norway) and $2 \mu \mathrm{g} / \mathrm{ml}$ ionomycin in R10 was added as a positive control to confirm sufficient expression 
medRxiv preprint doi: https://doi.org/10.1101/2022.02.10.22270789; this version posted February 14, 2022. The copyright holder for this preprint (which was not certified by peer review) is the author/funder, who has granted medRxiv a license to display the preprint in It is made available under a CC-BY-NC-ND 4.0 International license.

of the Fc receptor. RLUs for spikes were normalised to each other and between runs using CR3022. All samples were run head to head in the same experiment as were all variants tested.

\section{QUANTIFICATION AND STATISTICAL ANALYSIS}

Analyses were performed in Prism (v9; GraphPad Software Inc, San Diego, CA, USA). Nonparametric tests were used for all comparisons. The Mann-Whitney and Wilcoxon tests were used for unmatched and paired samples, respectively. The Friedman test with Dunns correction for multiple comparisons was used for matched comparisons across variants. All correlations reported are non-parametric Spearman's correlations. $P$ values less than 0.05 were considered to be statistically significant. 